【論 文】

UDC $: 711.12: 711.1$

\title{
近年の建物更新活動と共同住宅住民像からみた 都心居住地域の変貌の実態に関する研究
}

東京都港区を事例として

$\begin{array}{cccc}\text { 正会員 山 } & \text { 下 } & \text { 畺 } & \text { 悟* } \\ \text { 正会員 三 } & \text { 輪 } & \text { 恭 } & \text { 之** }\end{array}$

\section{1.はじめに}

都心居住の問題は，最近各方面で活発に議論され，社 会的にも大きくクローズアップされるようになったが, その論点は以下の 4 つに集約できよう。

1）ここ数年の地価の急激な高騰は, 都心部のみなら ず周辺部の住宅地にも波及し, 住宅取得価額, 家賃, 固 定資産税等，住居費が高まり，希望にあった広さ，立地 の住宅を得られないという問題を引き起こしている。そ して, 都心居住の問題を, こうした東京圈全域にわたる 住宅問題の典型もしくは元凶とする論1)。

2）都心部の住民登録人口は诚少し続けている。住民 登録人口は地方財政に大きくかかわるため，その減少は 好ましくなく，また，住民＝住民登録者ととらえる地方 自治体の存立を危うくするとする論 2 ),3)。

3）「都市」は, 人が集まり住み, 生活するからこそ「都 市」であるといえる。商業・業務ビルの増加に伴ない, 低密居住地区が都心業務地域から周辺の住宅地と思われ ていた地域にまで拡大している。低密居住地区の拡大は, 都市としての活力上も，安全上も問題を有するとする 論(4) 6)

4）現在の都心居住地域は，昔からそこに住む人々に とって住みにくい空間になってきている。近隣店舗の減 少による生活への支障や町内会活動の衰退が生じ，また， 直接的には，住宅保持費の上昇や地上げによる半強制的 立ち退き要求によって，転出せざるを得ない状況を生じ

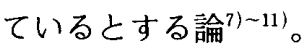

こうした都心居住問題の解決のためには，まず，議論 のベースとなる現状（実態）認識を的確に行うことが必 要であり, 本研究では, 丸の内・新橋等の都心業務地域 の縁辺部にあって，住機能の占める割合がまだ大きい都 心居住地域において, 上記 4 つの観点の中でも, 特に, (1) 3)の問題意識のとらえ方において, 低密居住地区は

*（財）森記念財団 主任研究員 $・$ 工博

** (財) 森記念財団 研究員

(1988 年 11 月 30 日原稿受理, 1989 年 6 月 28 日採用決定)
従来住宅地として安定していると思われていた都心居住 地域に拡大しているのか。(2) 4)の観点において, 都心 居住地域が, 既存住民 (本稿では持ち家層について検討。 借家層については別途議論を要する）を転出に追い込む 経済的状況にあるのか。以上の 2 点について，その実態 を明らかにすることを目的としたものである。

\section{2. 調査地区の選定と調査の方法}

\section{2-1 調查対象地区}

本研究では, 中心業務街の一部を形成し，一方で山の 手住宅地に連担し，業務色と住宅色の双方を併わせ持っ た，東京の都心 3 区の 1 つである港区の住宅地に着目し た。

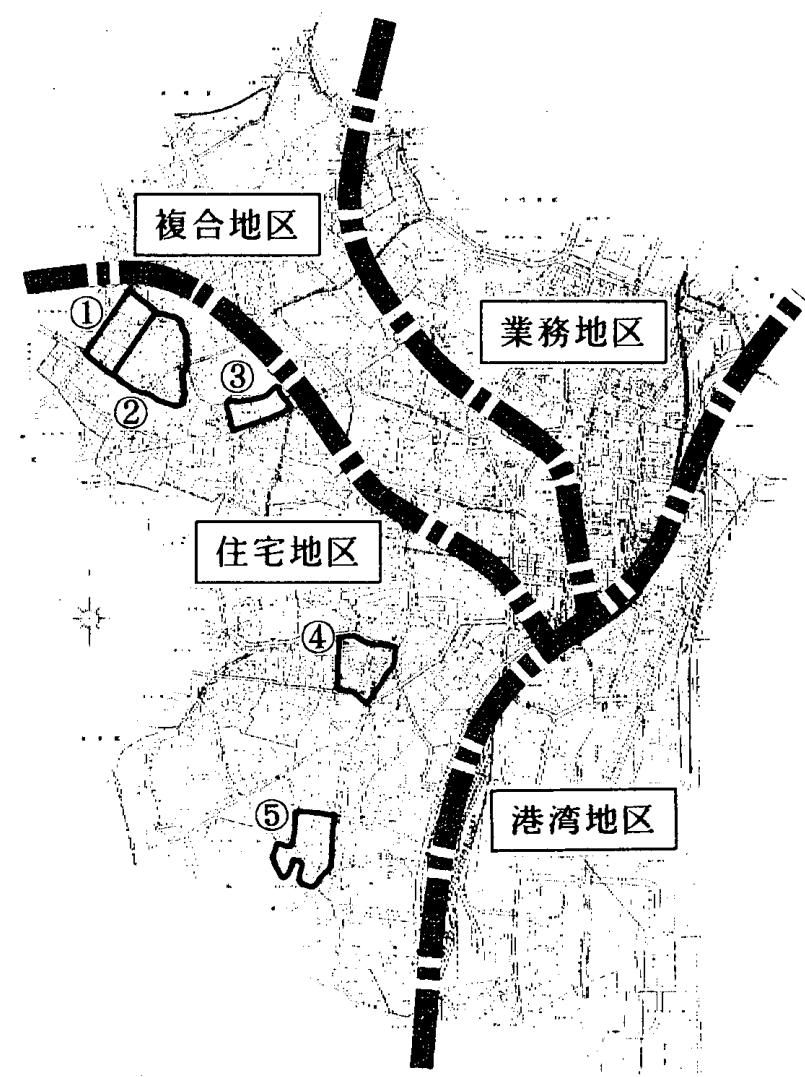

图一1＼cjkstart港区の地区区分および調查対象地区 
人口

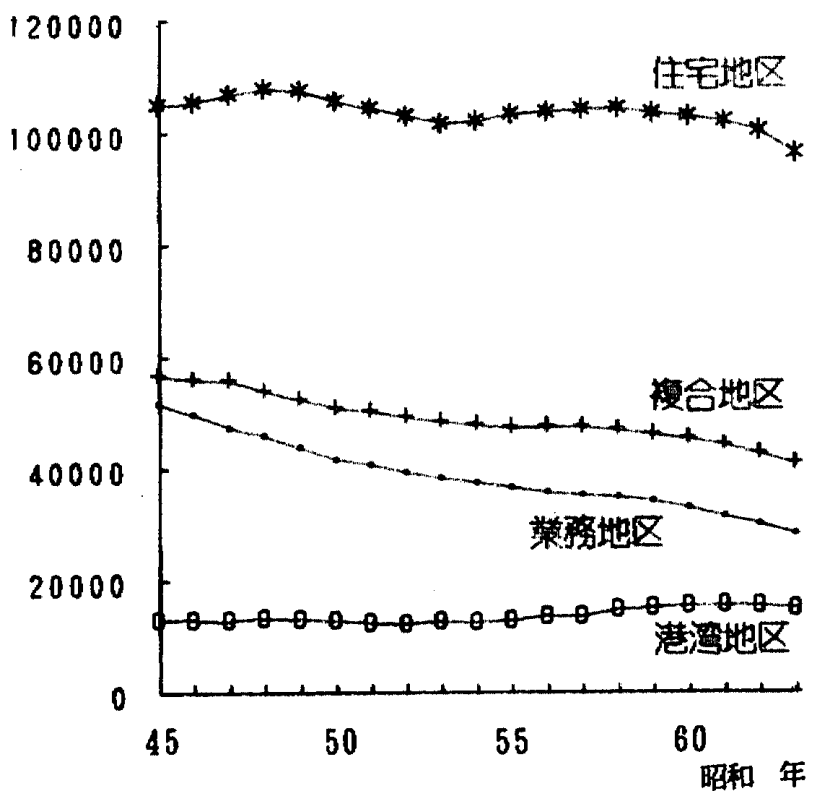

図一2 各地区の人口

港区は，その土地利用の特色から，I 業務地区，II 複 合地区， III住宅地区，IV港湾地区，の 4 地区に分けるこ とができる12)。

4 地区の人口は，I 業務地区と II 複合地区で漸減し， II住宅地区でほぼ横這い, IV港湾地区では微増している。 I 業務地区は，現在すでに業務施設中心の土地利用で, 今後も業務立地が進行し, 人口動態から予想しても業務 街として成熟する方向にあると思われる。また，II複合 地区も, 業務機能の進出が顕著で, 現在は I 業務地区に 準じた動向を呈している。これに対して囵住宅地区では, 住宅ストックが大きく, 今後も住宅主体の土地利用で推 移すると見られていたが, 住民登録人口はここ数年で娍 少に転じ，減少傾向が加速化しつつある。

住宅主体の地域で, 業務機能の進出を受け業務空間が 拡大し続けるのかどうかは, 都心居住を議論する上で重 要なポイントである。こうした 観点に基づき，本研究では，港 区における III住宅地区の中から 性格の異なる 5 町丁目を選定 し，調査分析を行った。

各地区の地域性は（表一1） のとおりである。

\section{2-2 調査の概要}

都心部の人口増減は，社会移 動によるものが大部分であり， 建物更新は, その社会移動を引 き起こす直接的な要因となる。 建物更新活動による都心居住地 域の居住空間の変貌状況を把握 するため, 昭和 55 年 62 年の
表一1 調査対象各地区の地域特性

\begin{tabular}{|l|l|}
\hline (1)南清山 3 丁目 & $\begin{array}{l}\text { 青山通りに面する住宅地。建替え } \\
\text { による土地利用転換が激しい。 }\end{array}$ \\
\hline (2)南青山 4 丁目 & $\begin{array}{l}\text { 閑静な山の手住宅街だが、マンシ } \\
\text { シの供給が活発である。 }\end{array}$ \\
\hline (3)西麻布 1丁目 & $\begin{array}{l}\text { 六本木に隣接しており、眒食店が } \\
\text { 多く見られる。 }\end{array}$ \\
\hline (4)白 金 1 丁目 & $\begin{array}{l}\text { 古川沿の準工業地域。小規模な工 } \\
\text { 場併用住宅が集積している。 }\end{array}$ \\
\hline (5)白金台 2丁目 & $\begin{array}{l}\text { 品川区に隣接する戸建住宅街。幹 } \\
\text { 線道路治も非高度利用敷地が多い。 }\end{array}$ \\
\hline
\end{tabular}

建築活動（建物の新築）にかかる土地建物の登記簿謄本 により，土地建物の面積，権利関係，建物用途を分析し， また, 従前従後の建物利用状況, 居住者を, 昭和 55 年 62 年両時点の住宅地図および現地踏査により確認した。

また, 都心部人口減少の実相と, 居住者の特徴を把握 するため, 調查対象地区の共同住宅全棟について, 現地 踏査結果と住民票とを照合し, 共同住宅の住民登録状況 をとらえた。

さらに,これらの調查の補足として, II 複合地区に属 する地域ではあるが，かつて収集した赤坂 7〜9丁目の マンション全棟, および芝 $2 丁$ 目の昭和 59 年の住民票 と昭和 55〜 59 年の住民票除票を分析し ${ }^{13)}$, 居住者の属 性および動態の特徴を把握した。

以上のような調查・分析を通じて, 低密居住地区が都 心居住地域に拡大しているのか, また, 建物更新により 住民が転出する状況にあるのかについて明らかにした。

\section{3. 建物更新活動からみた都心居住地域の変容}

3-1 建物形態の変化

昭和 55 年〜 62 年の 7 年間における建築活動をみると (表一2), 建物の用途は, 新築棟数 318 棟のうち, 住居

表一2 建築活動による建物用途の変化

\begin{tabular}{|c|c|c|c|c|c|c|c|}
\hline 従前 & $\frac{1}{P}$ 建住宅 & $\stackrel{2}{\text { ア }} \underset{\text { 寮 }}{ }$ & $\begin{array}{l}3 \\
\text { マンジョン }\end{array}$ & \begin{tabular}{|l}
4 \\
オフィス・店钱等 \\
侀用マンションン
\end{tabular} & $\begin{array}{l}5 \\
\text { オフィス・店 } \\
\text { 策等併用住宅 }\end{array}$ & $\begin{array}{l}6 \\
\text { オフ } \\
\text { 店 紏 等 }\end{array}$ & 合 \\
\hline $\begin{array}{l}1 \\
\text { F建住宅 }\end{array}$ & $\begin{array}{l}121 \\
(59.3) \\
(82.9]\end{array}$ & $\left(\begin{array}{c}6 \\
2.9 \\
54.5\end{array}\right)$ & $\begin{array}{l}30 \\
(14.7) \\
(61.2)\end{array}$ & $\begin{array}{c}7 \\
(3.4) \\
(30.4)\end{array}$ & $\begin{array}{l}24 \\
(11.8) \\
39.3)\end{array}$ & $\left\{\begin{array}{c}16 \\
7.8) \\
57.1]\end{array}\right.$ & $\begin{array}{l}204 \\
(100.0) \\
(64.2)\end{array}$ \\
\hline$\stackrel{2}{ア ハ-1}$ & $\left(\begin{array}{c}2 \\
15.4) \\
1.4\end{array}\right)$ & $\begin{array}{c}3 \\
(23.1) \\
(27: 3)\end{array}$ & $\begin{array}{c}3 \\
(23.1) \\
6.1)\end{array}$ & $\begin{array}{l}1 \\
\left(\begin{array}{l}1 \\
4.7\end{array}\right) \\
4.3\end{array}$ & $\left.\begin{array}{l}4 \\
(30.8) \\
6.6\end{array}\right)$ & $\left.\begin{array}{l}0 \\
\left(\begin{array}{l}0 \\
0.0\end{array}\right) \\
0.0\end{array}\right)$ & $\begin{array}{c}13 \\
(100.0) \\
4.1\end{array}$ \\
\hline 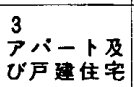 & $\left(\begin{array}{l}0 \\
0.0 \\
0.0\end{array}\right)$ & $\left(\begin{array}{l}0 \\
0.0 \\
0.0\end{array}\right)$ & $\begin{array}{c}2 \\
(66.7) \\
4.1)\end{array}$ & $\left(\begin{array}{l}0 \\
0.0 \\
0.0\end{array}\right)$ & $\left(\begin{array}{l}0 \\
0.0 \\
0.0\end{array}\right)$ & $\left(\begin{array}{c}1 \\
(33.3) \\
3.6\end{array}\right)$ & $\left.\begin{array}{c}3 \\
(100.0) \\
0.9\end{array}\right)$ \\
\hline $\begin{array}{l}\dot{4} \\
\text { 店 } \\
\text { 阱用住宅等 }\end{array}$ & $\begin{array}{l}2 \\
\left(\begin{array}{l}3.4 \\
1.4\end{array}\right)\end{array}$ & $\left(\begin{array}{l}1 \\
1.7) \\
9.1\end{array}\right]$ & $\left(\begin{array}{c}6 \\
(10.3) \\
12.2\end{array}\right)$ & $\left.\begin{array}{l}12 \\
(20.7) \\
52.2\end{array}\right)$ & $\begin{array}{l}30 \\
(51.7) \\
49.2]\end{array}$ & $\begin{array}{c}7 \\
(12.1) \\
(25.0)\end{array}$ & $\begin{array}{c}58 \\
(100.0) \\
(18.2) \\
\end{array}$ \\
\hline $\begin{array}{c}5 \\
\text { 空 } \\
\text { 地 }\end{array}$ & $\begin{array}{l}21 \\
(52.5) \\
14.4]\end{array}$ & $\left\{\begin{array}{l}1 \\
2.5) \\
9.1]\end{array}\right.$ & $\begin{array}{c}8 \\
(20.0) \\
(16.3)\end{array}$ & $\begin{array}{c}3 \\
(7.5) \\
(13.0) \\
\end{array}$ & $\begin{array}{l}3 \\
\left(\begin{array}{l}7.5 \\
4.9\end{array}\right.\end{array}$ & $\begin{array}{c}4 \\
(10.0) \\
(14.3)\end{array}$ & $\begin{array}{r}40 \\
(100.0) \\
{[12.6}\end{array}$ \\
\hline 站 & $\begin{array}{l}146 \\
(45.9) \\
(100.0)\end{array}$ & $\begin{array}{c}11 \\
\left(\begin{array}{c}11.5 \\
(100.0\end{array}\right)\end{array}$ & $\begin{array}{c}49 \\
(15.4) \\
(100.0]\end{array}$ & $\left(\begin{array}{c}23 \\
7.2\end{array}\right)$ & $\begin{array}{l}61 \\
(19.2) \\
(100.0)\end{array}$ & $\begin{array}{c}28 \\
(8.8) \\
(100.0)\end{array}$ & $\begin{array}{l}318 \\
(100.0) \\
(100.0)\end{array}$ \\
\hline
\end{tabular}

注) 㤓数は建替元後の数值でおる 
を含む建物が全体の 9 割強を占める。その半数は戸建住 宅であるが，これらは，ほとんどが老朽化等の理由で, 従前通り戸建住宅に建替わったものであり，都心といえ どもこうした户建住宅への建替えが最も大きなウエイト を占めている。

戸建住宅から戸建住宅以外の建物に建替わったものの 中では, マンションが最も多く, オフィス・店舗併用住 宅がそれに次いでいる。一方, 併用住宅は, 従後も併用 住宅に建替わるものが最も多い。

建替えという行為を契機に高度利用し, 自宅以外に収 益床 (あるいは自己使用の店舗・工場) を新設しながら も，従前用途は引き継がれる建築活動が多い。

いずれにせよ,オフィスや店舗ビルに建替わる場合も, その中に住居が含まれる例が多いことには注目すべきで ある。

\section{3-2 土地条件}

昭和 62 年における調查対象地区の総敷地数に対する, 昭和 55 年 62 年に建物更新が行われた敷地数の割合 を, 前面道路幅員別にみると, 幅員 $8 \mathrm{~m}$ 未満の敷地で は $13.4 \%$ （建築敷地数 $280 /$ 昭和 62 年時点の敷地数 $2085)$ であるのに対し，幅員 $8 \mathrm{~m}$ 以上の敷地では $11.4 \%$

(建築敷地数 $38 /$ 昭和 62 年時点の敷地数 333 ） と少な い。幹線道路沿いの建物は既に一とおりビル化しており， 昭和 55 年以降は, 建築活動の主流が, 戸建住宅を中心 とした内部市街地へ移行しつつあるといえる。

建物更新が行われた敷地のうち, 前面道路幅員 $8 \mathrm{~m}$ 未満で第二種住居専用地域内では, 半数以上が戸建住宅 の建設で，アパート・マンションを含めた住宅専用建築 物が $77 \%$ を占める。第二種住居専用地域内では, オフィ ス・店舗等の建築制限（2 階以下かつ $1500 \mathrm{~m}^{2}$ 以下）が よく効いた結果となっている(図一-3)。

これに対して, 幅員 $8 \mathrm{~m}$ 末満で第二種住居専用地域 以外の敷地では，専用共同住宅の割合は娍少し，併用住 宅の割合が非常に高いが，その一方で，戸建住宅が 42 \%と最も大きな割合を占めている。住専地域以外であ

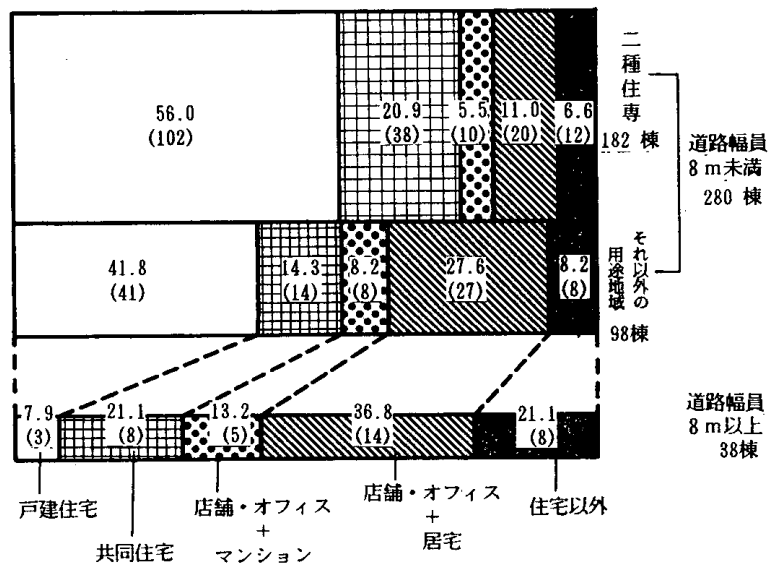

図-3 土地条件別建物更新敷地
れば住宅以外の用途の面積制限はないが, 前面道路が狭 く, 住居系用途が大部分を占める対象地区では, 建築可 能な容積率が $160 \%$ 2 $40 \%$ 程度に制限され, 高度利用 の際得られる収益床が少ないため, 資金力の乏しい建築 主によって用途転換は困難であり, 従後も依然として住 居系建物が主流となるものと考えられる。

対象地区での幅員 $8 \mathrm{~m}$ 以上の敷地では, 前面道路幅 員による容積規制を受けるところがなく，高度利用の実 現性が高く，オフィスや店舗等の非住居系用途を含んだ 建物の割合が高くなっている。

このように, 更新後の建物用途は, 前面道路幅員によ り大きく左右され，道路基盤の不良な地域が大半を占め る都心居住地域では, 住宅の立地が根強いという認識が できる。

また,ここ数年の地価の急激な高騰により,ディベロッ パーが新規に土地を取得してビルを建設しても採算性が 覀く, さらに, 住宅地域内では建築制限が厳しく大規模 なビルの建設は事実上不可能である。

これらの要因が, 住宅地の業務化に一定の歯止めをか けている。

3-3 住宅利用単位件数の変化

昭和 55 年一 62 年における建物更新活動により隇失ま たは新築された住戸，オフィス，店埔，工場の利用単位 件数を ${ }^{14}$, 住宅地図および現地踏査により確認した(表 $-3)$ 。

7 年間の新築数は隇失数を大きく上回り, 高度利用が 進行していることを示している15)。

住戸数の増分は, マンションの供給によるところが大 きい。例えば住宅色の強い白金では，広幅員主要幹線道 路沿いでオフィスビル建設のきざしが多少見受けられる が, 地区内部の建物更新により数多くのマンションが供 給されている。

一方，非住居用途では，小規模併用工場や自営の住宅 併用店舗等が滅失し，それらに代わり，新築ビルに入居 するオフィス・店舗およびマンションに入居するオフィ ス等が新たな形しして出現している。南青山や西麻布の ように業務地区に隣接する地域では, 用途地域や容積率

表-3 堿失, 新築建物の利用単位件数と人口・世带数の変化

\begin{tabular}{|c|c|c|c|c|}
\hline \multirow{3}{*}{$\begin{array}{l}\text { 利 } \\
\text { 用 } \\
\text { 單の } \\
\text { 位変 } \\
\text { 数化 }\end{array}$} & & $\underset{\text { S. } 5.55 \sim 62}{62}$ & $\underset{\text { S. }}{\text { 新築数 }} 6$ & $\begin{array}{l}\text { 差し引き } \\
\text { 増加数 }\end{array}$ \\
\hline & 住 居 & 726 & 1039 & 253 \\
\hline & 非住居 & 97 & 422 & 325 \\
\hline \multirow{3}{*}{$\begin{array}{l}\text { 人 } \\
\text { 口 } \\
\text { 世蝶の } \\
\text { 曼変 } \\
\text { 数化 }\end{array}$} & & S.55 & S. 62 & $\begin{array}{l}\text { S. } 55 \sim 62 \\
\text { 增加数 }\end{array}$ \\
\hline & 人口 & 15.008 & 14.010 & $\Delta 1,078$ \\
\hline & 世帯数 & 6,519 & 6.554 & 35 \\
\hline
\end{tabular}


表-4 建物更新時の住民の行動および権利関係の変化

\begin{tabular}{|c|c|c|c|c|c|}
\hline $\begin{array}{l}\text { 従 } \\
\text { 前 }\end{array}$ & 従 & 戸建住宅 & $\begin{array}{l}\text { マンショ} \\
\text { ン・ビル }\end{array}$ & それ以外 & 合 \\
\hline \multirow{3}{*}{$\begin{array}{l}\text { 戸 } \\
\text { 建 } \\
\text { 住 } \\
\text { 宅 }\end{array}$} & $\begin{array}{l}\text { 残 } \\
\text { 留 }\end{array}$ & $\begin{array}{c}83 \quad[0] \\
(74.7)\end{array}$ & $\begin{array}{l}38 \quad[0] \\
(58.5) \\
\end{array}$ & $\begin{array}{l}11 \quad[0] \\
(44.0)\end{array}$ & $\begin{array}{l}132 \quad[0] \\
(65.7)\end{array}$ \\
\hline & $\begin{array}{l}\text { 転 } \\
\text { 出 } \\
\end{array}$ & $\begin{array}{l}28[26] \\
(25.3) \\
\end{array}$ & $\begin{array}{l}27[22] \\
(41.5) \\
\end{array}$ & $\begin{array}{l}14[12] \\
(56.0) \\
\end{array}$ & $\begin{array}{l}69[60] \\
(34.3) \\
\end{array}$ \\
\hline & $\begin{array}{l}\text { 小 } \\
\text { 計 } \\
\end{array}$ & $111[26]$ & $65[22]$ & $25[12]$ & $201[60]$ \\
\hline \multirow{3}{*}{$\begin{array}{l}\text { 併 } \\
\text { 用 } \\
\text { 住 } \\
\text { 宅 } \\
\text { 等 }\end{array}$} & 线 & $\begin{array}{c}2 \quad[0] \\
(100.0) \\
\end{array}$ & $\begin{array}{l}24 \quad[0] \\
(72.7) \\
\end{array}$ & $\begin{array}{c}11 \quad[0] \\
(100.0)\end{array}$ & $\begin{array}{l}37 \quad[0] \\
(80.4) \\
\end{array}$ \\
\hline & $\begin{array}{r}\text { 転 } \\
\text { 出 }\end{array}$ & $\begin{array}{l}0 \quad[0] \\
(0.0)\end{array}$ & $\begin{array}{c}9 \quad[9] \\
(27.3) \\
\end{array}$ & $\begin{array}{l}0 \quad[0] \\
(0.0) \\
\end{array}$ & $\begin{array}{c}9 \quad[9] \\
(19.6) \\
\end{array}$ \\
\hline & $\begin{array}{l}\text { 小 } \\
\text { 計 }\end{array}$ & $2 \quad[0]$ & $33 \quad[9]$ & $11[0]$ & $46 \quad[9]$ \\
\hline \multirow[t]{2}{*}{ 合 } & 残 & $\begin{array}{r}85 \quad[0] \\
(75.2) \\
\end{array}$ & $\begin{array}{c}62 \quad[0] \\
(63.3) \\
\end{array}$ & $\begin{array}{l}22 \quad[0] \\
(61.1) \\
\end{array}$ & $\begin{array}{l}169 \quad[0] \\
(68.4)\end{array}$ \\
\hline & $\begin{array}{r}\text { 出 } \\
\text { 出 }\end{array}$ & $\begin{array}{l}28[26] \\
(24.8) \\
\end{array}$ & $\begin{array}{l}36[31] \\
(36.7) \\
\end{array}$ & $\begin{array}{l}14[12] \\
(38.9) \\
\end{array}$ & $\begin{array}{l}78[69] \\
(31.6) \\
\end{array}$ \\
\hline 計 & $\begin{array}{l}\text { 小 } \\
\text { 計 } \\
\end{array}$ & $113[26]$ & $98[31]$ & $36[12]$ & 247 [69] \\
\hline
\end{tabular}

の規制を受けながらも, 小規模オフィスが居宅, マンショ ンと併設で地区内部に浸透し始めている。

しかし, 住宅利用単位件数（住戸数）が 253 増加して いるにもかかわらず，世帯数の増加は 35 にとよ゙まり， 逆に人口は 1078 人減少している。その理由としては, 新築住宅に住民登録をしない世帯が多数入居しているこ $\left\llcorner^{16)}\right.$, 戸建住宅や併用住宅からマンションへと住宅の形 態を変化させている中で転入世帯が小規模化しつつあ る ${ }^{17)} こ と$ 等が考えられる。

\section{4. 建物更新時における住民の行動}

昭和 55 年 62 年の建物更新活動時における従前居住 者の行動を,土地建物の権利関係については登記簿謄本, 住民の転出・残留については昭和 55 年, 62 年両時点の 住宅地図および現地踏査により確認した(表一4)。

対象地区内の建物更新件数 318 件のうち, 従前（昭和 55 年時）に居住者がいた建物は 247 件 $^{18)}$ あっこれら のうち, 建替え後も住民が継続して居住している建物は， 169 件 (68.4\%) ある。従後の建物形態別にみると，戸 建住宅に建替わった場合は $75.2 \%$ (113 件中 85 件) が 残留している。户建住宅の定着率が高いのは，転出・残 留の議論の対象にならない, 自宅の老朽化に伴う建替え が多いからであろう。一方, マンション・ビルに建替わっ た場合の残留率も $63.3 \%(62 / 98)$ と高い定着志向を示 している。

建物更新時の土地建物の権利関係についてみると, 従 前居住者が転出した場合は, $88.5 \%(69 / 78)$ が土地ま たは建物の所有権を売却しており ${ }^{19)}$ ，従前居住者が継続 して居住している場合には, 居住者が所有権を売却した
事例はなかった。

このように, 建物更新時の居住者の行動パターンは, 土地建物の権利を保持したまま住み続ける者と, 土地建 物を売却して転出する者の 2 とおりに大別できるが，転 出しても所有権は売却されなかったケースも 9 件あっ た。この中で, マンション・ビルになったもの 5 件は, 住む場所は別に求めながら, 建物は賃貸し不動産経営に 乗り出しており，投資の対象として都心居住地にかかわ りを持ち続けている例である。なお, 残りは, 居住者が 転出し, 所有者の利用に帰したものが 1 件, 逆に, 所有 者が転出し借家にしたものが 2 件，贈与して転出したも のが 1 件である。

さらに詳細に，従前の建物形態別にみると，マンショ ン・ビルに建替わる場合には，従前が戸建住宅であった ものの残留率が $58.5 \%$ (65 件中 38 件)であるのに対し， 従前が併用住宅等の場合は $72.7 \%(24 / 33)$ と高く, マ ンション・ビル以外に建替わったものも含めた残留率も 従前が併用住宅等の方がかなり高い。

併用住宅居住者には，居住継続の問題以外に，自己の 商売・事業の存続問題があり, 自己の事業を存続あるい は不動産経営に転換しながらも居住し続ける志向が強い ことを示している ${ }^{20)}$ 。自営型工場併用住宅が多い白金地 区の建物更新活動をみると，低層部に工場を残し，上層 部をマンション・オフィスとして貨貸する例がいくつか あった ${ }^{21)}$ 。白金地区のような，零細で，大手の下請けで 金属・部品等を加工する工場は, 都心にあって小回りの きく対応をする上ではメリットがあり ${ }^{22)}$, 開発の波は押 し寄せているものの，まだまだ工場として残るものも多 いようだ。

マンションや，オフィス・店舗ビルに建替えて不動産 経営に乗り出し，自らも居住を継続するのが，都心居住 地域における既存住民の建物更新時の典型的な行動パ ターンであり，こうした傾向は，港区の芝地区 ${ }^{23)}$ や，千 代田区の神田地区 ${ }^{24)}$ のような下町地域においてもよくみ られる。

また，オフィス・店赤ビルの場合には，自宅の玄関を 目立たない場所に設け，テナントとの動線を区別するな ビ, 建築計画の面での工夫もみられ，敷地の有効利用を しながら自己の住環境は確保しようとする姿勢がうかが える。

\section{5. 都心居住地域における建物更新の可能性}

都心居住地域における高度利用が，主に地主が建替え 主体となって行われているわけだが，その背景には，(1) 利便性, 知名度, 環境面で良好な住宅地であり, 土地の 経済的価値も高く,地主の定住意識が強い。(2)オフィス・ マンション需要が旺盛である。(3)土地買収による開発が 困難になってきており，土地所有者でなければ有効利用 できない。等の理由があげられる。 
表一5 地主による自宅付賃貸ビル建設の設定条件

\begin{tabular}{|c|c|c|c|}
\hline \multicolumn{4}{|c|}{ 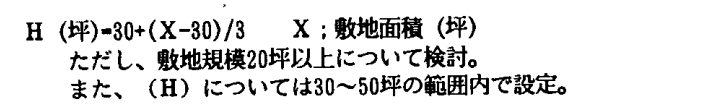 } \\
\hline \multicolumn{4}{|c|}{ （2地主は建築費を全額借り入れることとする。 } \\
\hline \multicolumn{4}{|c|}{ (3)立地と傎貸用途別の家賃およひ敷金を以下のように設定。 } \\
\hline & & 店埔・オフィス & マンション \\
\hline \multirow{2}{*}{$\begin{array}{l}\text { 南青山 } 3 \text { 丁目 } \\
\text { 南青山 } 4 \text { 丁目 } \\
\text { 西麻布 } 1 \text { 丁目 }\end{array}$} & 家貨 (Y) & 2.5 (万円 $/$ 月・坪 $)$ & 2.0 (万円 $/$ 月・坪) \\
\hline & 教金 (S) & 50 (万円 $/$ 月・坪) & 6 (万円 $/$ 月・坪 $)$ \\
\hline \multirow{2}{*}{$\begin{array}{l}\text { 白 金 } 1 \text { 丁目 } \\
\text { 白金台 } 2 丁 \text { 目 }\end{array}$} & 家貨 (Y) & 2.0 (万円 $/$ 月・坪) & 1.5 (万円 $/$ 月・坪) \\
\hline & 数金 $(\mathrm{S})$ & $40($ 万円 $/$ 月・坪 $)$ & 4.5 (万円 /月・坪) \\
\hline
\end{tabular}

(4)建築費単価; $A=100$ (万円 $/$ 坪)

(5)其室有效率； $\mathrm{U}=0.8$

(6)家貨収入に占めろ諸释費 (公租公課等) 割合; $K=0.2$

なお、当該ビルの不動産所得に対する税金については

別途手当てでるものとする。

(7利用容皘率は前面道路愊員により以下の 3 タイプに設定。

\begin{tabular}{|c|c|}
\hline 利用容積率 (V) & 前面道路愊員 \\
\hline $160 \%$ & 4 回末満 \\
\hline $240 \%$ & $4 \mathrm{a} \sim 8 \mathrm{~m}$ (白金 1 丁目 $4 \mathrm{~m}$ 末满) \\
\hline $300 \%$ & $8 \mathrm{~m}$ 以上 (白金 1 丁 \\
\hline
\end{tabular}

(8)借入れ金返済は、元利均等20年返济、金利 $6.5 \%$ とする。 よって、年間返済額二借入れ金総額 $\times 0.091$ となる。

港区には 1000 万円／坪以下の土地はなく，借地権割 合は 8 割以上に達するといわれている。こうした状況下 で, 平均的な宅地を所有する地主・借地人は, 数億の資 産家であり，それだけ行動の選択の幅が広がることにな る。

また，都心居住地域において地主が自宅付き貨貸ビル を建設することは，(1)優良テナント獲得による安定した 貢料収入の確保，(2)借家権相当分の土地建物相続税評価 額低減（貸家建付地評価は約 $20 \%$ ，貸家評価は約 $30 \%$ の低娍）による節税効果, (3)自己資産を不動産評価にす ることに課税遺産額の軽減（建物評価額は建築費の約 $60 \%)$ ，(4)負担付贈与の活用，(5)建物を相続人出資の法 人所有にし, 地代据え置きによる土地含み益の獲得等, 数多くのメリットがある。

ところで, 港区住宅地域における地主の有効利用型建 替えの可能性はよ゙うであろうか。

地主が自宅付き貨貸ビルを建設する場合, (1)建設資金 の捻出, (2)企画, 設計, 管理, 運営等のノウハウの取得, (3)テナントの確保, の 3 点が大きな課題になる。

このうち, (2)については, 土地柄から優秀なコンサル タントや建設会社が付きやすく, これらの専門家に任せ ればよい。(3については, 現時点では都心部のオフィス・ マンション需要は旺盛であり, また, 事業受託方式や新 借地方式など，ノウハウを提供する側のディベロッパー がテナント確保のリスクを負うやり方もある。(1)につい
表一6 各地区前面道路幅員別有効利用可能敷地数

\begin{tabular}{|c|c|c|c|c|c|c|c|}
\hline & \multirow[b]{2}{*}{$\begin{array}{l}\text { 前面道路 } \\
\text { 幅 角 }\end{array}$} & \multirow{2}{*}{$\begin{array}{c}\text { (A) } \\
\text { 数地数 }\end{array}$} & \multirow{2}{*}{$\begin{array}{c}\text { (B) } \\
\text { (A) のうち } \\
\text { ビル化して } \\
\text { Wない籹地 } \\
\end{array}$} & \multicolumn{2}{|c|}{ 店甜・オフィスにするとを } & \multicolumn{2}{|c|}{ マンションにするとき } \\
\hline & & & & 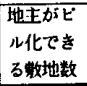 & $\begin{array}{l}\text { (B) に対 } \\
\text { \$ろ比率 } \\
(\%)\end{array}$ & $\begin{array}{l}\text { 地主がビ } \\
\text { ル化でき } \\
\text { 万隺地数 }\end{array}$ & $\begin{array}{l}\text { (B) に対 } \\
\text { する比称 } \\
\text { (\%) }\end{array}$ \\
\hline \multirow{4}{*}{$\begin{array}{l}\text { 南青山 } \\
3 \text { 丁目 }\end{array}$} & 40末 末満 & 274 & 231 & 139 & 60.2 & 70 & 30.3 \\
\hline & $4 \sim 8 \mathrm{~m}$ & 111 & 85 & 72 & 84.7 & 63 & 74.1 \\
\hline & $8 \mathrm{~m}$ 以上 & 66 & 26 & 23 & 88.5 & 23 & 88.5 \\
\hline & 合 計 & 451 & 342 & 234 & 68.4 & 156 & 45.6 \\
\hline \multirow{4}{*}{$\begin{array}{c}\text { 南青山 } \\
4 \text { 丁丁目 }\end{array}$} & 4血末萿 & 421 & 378 & 254 & 67.2 & 141 & 37.3 \\
\hline & $4 \sim 8 \mathrm{~m}$ & 100 & 70 & 68 & 97.1 & 62 & 88.6 \\
\hline & $4 \mathrm{~m}$ 以上 & 71 & 51 & 49 & 96.1 & 49 & 96.1 \\
\hline & 合計 & 592 & 499 & 371 & 74.3 & 252 & 50.5 \\
\hline \multirow{4}{*}{$\begin{array}{l}\text { 西麻布 } \\
1 \text { 丁目 }\end{array}$} & 4 四末满 & 123 & 109 & 46 & 42.2 & 19 & 17.4 \\
\hline & $4 \sim 8 \pi$ & 165 & 130 & 99 & 76.2 & 82 & 63.1 \\
\hline & $8 \mathrm{~m}$ 以上 & 87 & 40 & 29 & 72.5 & 29 & 72.5 \\
\hline & & 375 & 279 & 174 & 62.4 & 130 & 46.6 \\
\hline \multirow{4}{*}{$\begin{array}{l}\text { 白金 } \\
\text { 1丁目 }\end{array}$} & 4 【1 末满 & 297 & 289 & 159 & 55.0 & 19 & 6.6 \\
\hline & $4 \sim 8 \div$ & 275 & 243 & 178 & 73.3 & 178 & 73.3 \\
\hline & 8自以上 & 100 & 82 & 61 & 74.4 & 61 & 74.4 \\
\hline & & 672 & 614 & 398 & 64.8 & 258 & 42.0 \\
\hline \multirow{4}{*}{$\begin{array}{l}\text { 白金台 } \\
2 \text { 丁目 }\end{array}$} & 4n 末 末满 & 235 & 228 & 88 & 38.6 & 11 & 4.8 \\
\hline & $4 \sim 8 \mathrm{~m}$ & 234 & 216 & 184 & 85.2 & 83 & 38.4 \\
\hline & $8 \mathrm{~m}$ 以上 & 45 & 26 & 17 & 65.4 & 17 & 65.4 \\
\hline & & 514 & 470 & 289 & 61.5 & 111 & 23.6 \\
\hline \multirow{4}{*}{$\begin{array}{l}5 \text { 地区 } \\
\text { 合 計 }\end{array}$} & 4 日来满 & 1350 & 1235 & 686 & 55.5 & 260 & 21.1 \\
\hline & $4 \sim 8$ m & 885 & 744 & 601 & 80.8 & 468 & 62.9 \\
\hline & 8 凸以上 & 369 & 225 & 179 & 79.6 & 179 & 79.6 \\
\hline & 合計 & 2604 & 2204 & 1466 & 66.5 & 907 & 41.2 \\
\hline
\end{tabular}

ては，個人地主であるから，建築費を自己資金で賄いう るケースはまれで, ほとんどの地主ば土地建物を担保に 資金をつくり，ビル建設，テナント獲得後，賃料の一部 を建築費借入れの返済に充当することになる。

以下で，(2)，(3)に関する条件は十分にクリアできるも のとして，資金力のない地主が自宅付貨貸ビルを建設す る際の，敷地条件による違いを検討してみる。

（表一5）に示した条件の下で，年間貫料収入=年間 借り入れ金返済額となるためには，

$$
\begin{array}{rl}
12 & \mathrm{UY}(1-\mathrm{K})(\mathrm{XV} / 100-\mathrm{H}) \\
& =0.091[\mathrm{AXV} / 100-\mathrm{US}(\mathrm{XV} / 100-\mathrm{H})]
\end{array}
$$

となる。（1）式を満たすための敷地規模（必要最低限 敷地規模）を算出し，各地区各敷地条件ごとに，必要規 模以上の敷地がどれだけあるかを示したのが（表一6） である。

マンションにする場合の有効利用可能敷地数を見る 之, 白金 1 丁目, 白金台 2 丁目の前面道路幅員 $4 \mathrm{~m}$ 末 満敷地では有効利用のできる敷地が極端に少ない。特に 白金台 $2 丁$ 目では, トータルでもビル化していない敷地 の $23.6 \%$ にとどまっている。

店舗，オフィスはマンションより賃貸条件がよく，各 地区とも過半数の敷地で有効利用が可能であるが，白金 1 丁目, 白金台 2 丁目では, 現在のところ店舖・オフィ スの立地は考えにくい。この 2 地区は，ビル化していな い敷地が多く，住宅立地を主体としてしばらくは安定し ていくものと思われる。

南青山 $3 \cdot 4$ 丁目, 西麻布 1 丁目は, 他の地区より家 貨を高く設定できる分，有効利用の実現性が高くなって いる。

このように, 経済的側面からみれば,地主が主体となっ 
て建替えを行うことのできる敷地が数多 く存在していることがわかる。

\section{6. 都心居住地域における共同住宅住 民の特幑}

都心居住地域における住宅は，その形 態を戸建住宅・併用住宅からマンショ ン・住宅併用ビルへと変化させている が, 本項では，これら共同住宅における 住民像の一面を探った。

\section{6-1 住民登録状況}

共同住宅入居者の住民登録状況は（表一7）のとおり であった25)。

登録率調査は，各共同住宅の住居部分について郵便受 を見，(1)居住が確認できる住戸(郵便受に個人名の表札 が出ているもの), (2)オフィス利用が確認できる住戸 (郵 便受に法人名が出ていもの), (3)表札がなく, 居住・非 居住が不明な住戸に分類し，次に，住民登録者りストを 閲覧し，住戸ごとに住民登録者の有無を確認した。した がって, 登録率も, その分母のとり方によって, 数種類 の考え方ができる。

まず，居住が確認される住戸の登録率は $67.7 \%$ であ り, 表札を出している割には低いと思われる結果である。 逆に，居住不明住戸で $43.5 \%$ もの住戸が登録している のは特徵的である。管理人へのヒアリングにより, 表札 の出ていない住戸でも空室はほとんど無いことが判明し たが，表札を出さず匿名性を重視している点を考虑すれ ば高い登録率であるといえる。

一方，オフィス利用住戸のうち，16.6\%方住民登録 していたが，この中には，住居を兼ねたものもいくつか あり，また，仕事上の都合等で港区に登録していること も考えられる。

共同住宅を, 昭和 55 年以前建築のものとそれ以降に 建築のものとに分けてみると,居住不明の住戸を除いて， 昭和 54 年以前に建築された共同住宅の登録率の方が高 い。新しいマンションの登録率が若干ながら低下してい るのは，住民登録をしない入居者が年々増加しているこ とをうかがわせる。

次に，マンションの登録率別棟数分布をみると（図一 4)，登録率 $60 \%$ 台をピークに分布しているが，下方は， 登録率 1 ケ夕台まで 15 棟前後むらなく分布しているが, 上方は, $90 \%$ 台で急減している。

また，登録率 $80 \%$ 台を除き，一棟当たり平均戸数は おおむ权登録率が高くなるほど多い。戸数規模の大きな マンションは, 一般的に管理体制が整っており，「住宅」 としての意識が強く，まじめに住民登録する住民が多い と推測される。

こうした住民登録率の減少は，都心部におけるマン ションの利用の仕方が多様化していることを表してい

$-68-$
表-7 共同住宅入居者の住民登録状況

\begin{tabular}{|c|c|c|c|c|c|c|c|c|}
\hline \multicolumn{4}{|c|}{ 住戸数（うち登録住戸数） } & \multicolumn{3}{|c|}{ 登 } & \multicolumn{2}{|c|}{ (\%) } \\
\hline 居住 & (2)オフィス & (3)不明 & (4)合 計 & (1) & (2) & (3) & (1) + (3) & (4) \\
\hline $\begin{array}{l}1690 \\
1151)\end{array}$ & $\begin{array}{l}346 \\
(58)\end{array}$ & $\begin{array}{c}442 \\
(184)\end{array}$ & $\begin{array}{c}2520 \\
(1455)\end{array}$ & 68.1 & 16.8 & 41.6 & 62.7 & 57.7 \\
\hline $\begin{array}{l}412 \\
(273)\end{array}$ & $\begin{array}{l}118 \\
(19)\end{array}$ & $\begin{array}{c}252 \\
(118)\end{array}$ & $\begin{array}{c}813 \\
(419)\end{array}$ & 66.3 & 16.1 & 46.8 & 58.9 & 51.5 \\
\hline $\begin{array}{l}102 \\
424)\end{array}$ & $\begin{array}{l}464 \\
(77)\end{array}$ & $\begin{array}{c}694 \\
\langle 302)\end{array}$ & $\begin{array}{c}3333 \\
(1874)\end{array}$ & 67.7 & 16.6 & 43.5 & 61.7 & 56.2 \\
\hline
\end{tabular}

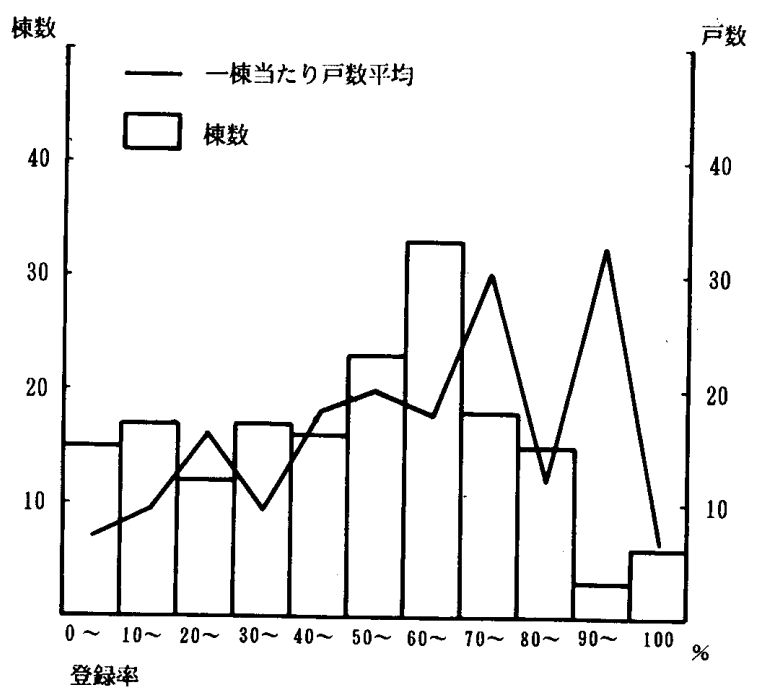

図一4 マンションの登録率別棟数分布

表-8 居住年数別転入時家族夕イプ別転出世帯数

\begin{tabular}{|c|c|c|c|c|c|c|}
\hline $\begin{array}{l}\text { 家族 } \\
\text { 年数 }\end{array}$ & 男性策身者 & 女性学身者 & 夫のの & 夫媞十子供 & * の他 & 合 \\
\hline 10年〜 & $\begin{array}{r}2 \\
\left(\begin{array}{r}15.4 \\
(2.4)\end{array}\right)\end{array}$ & $\left.\begin{array}{c}3 \\
(23.1 \\
3.5\end{array}\right)$ & $\left.\begin{array}{c}3 \\
(23.1) \\
9.4\end{array}\right)$ & $\begin{array}{r}4 \\
(30.8) \\
(9.8 \\
\end{array}$ & $\begin{array}{l}1 \\
\left(\begin{array}{l}7.7 \\
6.7\end{array}\right) \\
\end{array}$ & $\begin{array}{c}13 \\
(100.0) \\
(5.1)\end{array}$ \\
\hline $5 \sim 9$ & $\begin{array}{c}8 \\
\left(\begin{array}{c}20.0 \\
9.5\end{array}\right) \\
\end{array}$ & $\begin{array}{l}11 \\
(27.5) \\
(12.9) \\
\end{array}$ & $\begin{array}{c}9 \\
(22.5) \\
(28.1)\end{array}$ & $\begin{array}{c}9 \\
(22.5) \\
(22.0) \\
\end{array}$ & $\begin{array}{c}3 \\
(7.5) \\
(20.0) \\
\end{array}$ & $\begin{array}{c}40 \\
(100.0) \\
(15.6)\end{array}$ \\
\hline $3 \sim 4$ & $\begin{array}{r}8 \\
(19.5) \\
(9.5) \\
\end{array}$ & $\begin{array}{l}13 \\
(31.7) \\
{[15.3}\end{array}$ & $\left.\begin{array}{c}8 \\
(19.5) \\
(25.0\end{array}\right)$ & $\begin{array}{c}9 \\
(22.0) \\
(22.0) \\
\end{array}$ & $\left(\begin{array}{c}3 \\
7.3 \\
(20.0\end{array}\right)$ & $\begin{array}{c}41 \\
(100.0) \\
{[16.0}\end{array}$ \\
\hline 2 & $\left.\begin{array}{r}7 \\
(25.9) \\
8.3\end{array}\right]$ & $\begin{array}{l}10 \\
(37.0) \\
(11.8)\end{array}$ & $\left(\begin{array}{c}3 \\
(11.1) \\
9.4\end{array}\right)$ & $\begin{array}{c}7 \\
(25.9) \\
(17.1) \\
\end{array}$ & $\left(\begin{array}{l}0 \\
0.0 \\
0.0\end{array}\right)$ & $\begin{array}{c}27 \\
(100.0) \\
(10.5) \\
\end{array}$ \\
\hline 1 & $\begin{array}{l}17 \\
(34.0) \\
(20.2) \\
\end{array}$ & $\begin{array}{r}24 \\
(48.0) \\
(28.2) \\
\end{array}$ & $\begin{array}{l}2 \\
\left(\begin{array}{l}4.0 \\
6.3\end{array}\right) \\
\end{array}$ & 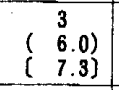 & $\begin{array}{r}4 \\
\left(\begin{array}{r}8.0 \\
(26.7)\end{array}\right. \\
\end{array}$ & $\begin{array}{c}50 \\
(100.0) \\
(10.5)\end{array}$ \\
\hline 0 & $\begin{array}{l}42 \\
(48.8) \\
(50.0) \\
\end{array}$ & $\begin{array}{l}24 \\
(27.9) \\
{[28.2]} \\
\end{array}$ & $\begin{array}{c}7 \\
\left(\begin{array}{c}8.1 \\
21.9\end{array}\right. \\
\end{array}$ & $\left(\begin{array}{c}9 \\
(10.5) \\
22.0\end{array}\right)$ & $\begin{array}{r}4 \\
\left(\begin{array}{r}4.7 \\
(26.7\end{array}\right) \\
\end{array}$ & $\begin{array}{c}85 \\
(100.0) \\
(33.5) \\
\end{array}$ \\
\hline 合 है & $\begin{array}{r}84 \\
(32.7) \\
(100.0) \\
\end{array}$ & $\begin{array}{c}85 \\
(33.1) \\
(100.0)\end{array}$ & $\begin{array}{r}32 \\
(12.5) \\
{[100.0)} \\
\end{array}$ & $\begin{array}{r}41 \\
(16.0) \\
(100.0) \\
\end{array}$ & $\begin{array}{c}15 \\
(5.8) \\
(100.0)\end{array}$ & $\begin{array}{l}257 \\
(100.0) \\
(100.0)\end{array}$ \\
\hline 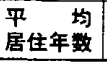 & 1年11々月 & 2 年 8 ヶ月 & 4 年 5 ヶ月 & 3 年11ヶ月 & З年11ヶ月 & 2 年11ヶ月 \\
\hline
\end{tabular}

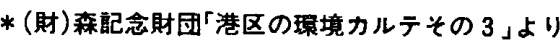

琱查対象は赤坂 7、8、9丁目のうち除票のあるもの257戸

る。調査対象地区内マンション住民へのヒアリングによ ればオフィス利用以外にも，ウィークデー居住やセカン ドハウス的利用, 投資の対象として購入し縁故者や第三 者に賃貸している例なざが確認できた ${ }^{26)}$ 。

6-2 共同住宅住民の定着性

赤坂 7 -9丁目のマンション, 芝 2 丁目全域の住民基 本台帳により, 都心居住地域における住民の定着性を事 

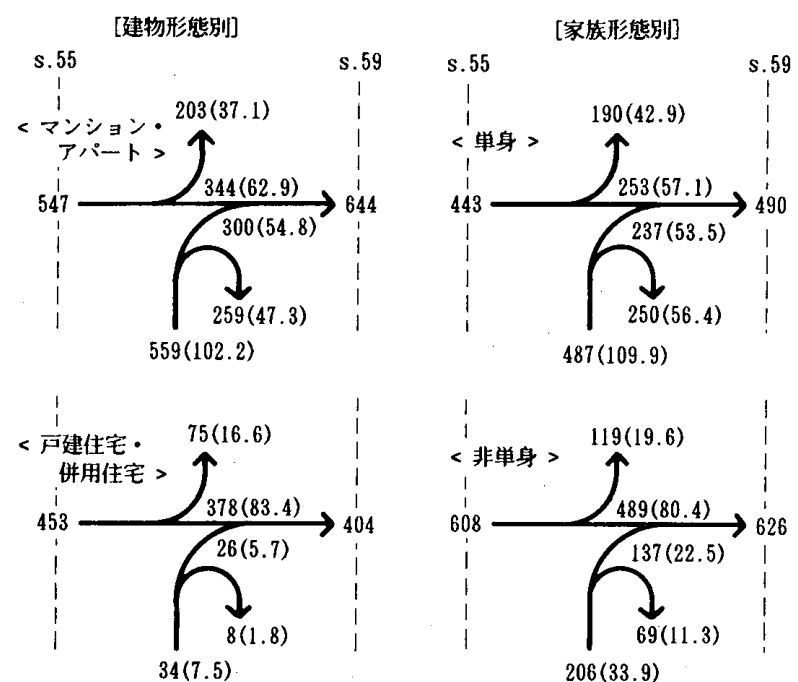

图一-5 芝地区住民登録世帯の世帯動態

例的にみた 27 。

（表一8）をみると，赤坂地区マンションでは，転入時 の家族タイプは単身者が $65.8 \%$ を占め，男女ほぼ同数 である。男性単身者は居住年数 1 年末満が半数を占めて いるが，女性単身者は比較的居住年数が長い。しかし， 全体の平均居住歴は 2 年 11 力月であり, 定着性の薄さ をうかがわせる。

マンション住民の希薄な定着性は芝 $2 丁$ 丁目の世帯動態 をみてもわかる（図一5）。戸建住宅・併用住宅では，そ の数が減少しているため転出世帯がかなり多いが，転入 世帯はほとんどない。これに対し，アパート・マンショ ン世帯は，入れ替わりが激しく，昭和 55 年～ 59 年に転 入した世帯のうち半数近くは昭和 59 年までに転出して いる。家族形態別にみると, 入れ替わり現象の主流は単 身世帯であることがわかる。

\section{7.まとめ}

都心居住問題の解決方策の検討に当たっては, 以下の 実態の踏まえることが必要であろう。

ここ数年の建築活動は住宅床を含む建物の建設が中心 で，その形態を戸建住宅・併用住宅からマンションへと 変化させながら，戸数は大幅に増加している。

住民登録人口が減少しているのに対し，実際には住戸 数が増加し,しかも空き室がほとんどない事実をみると， 非登録人口が増加し，結果として実質的な人口は減少し ていないと考えざるを得ない。以上の点から，都心業務 地域のような低密居住地区は, 港区住宅地区に代表され るような都心居住地域にまで拡大しているとはいえな い。

また，マンションは，住宅以外の利用があり，入れ替 わりも激しく，定住性も薄い。戸建住宅や併用住宅のマ ンション化，ビル化によって，こうした住民が都心人口 に占める割合はますます高まると考えられる。

一方, 都心に土地を有する既存住民で, 独自に高度利
用できる立場にある者は少なくなく，彼らは住み続ける ことも十分可能で，選択の幅は大きい。建替え活動の実 態は，土地建物を保有したまま高度利用し，居住を継続 する行為が主流である。この状況からは，地価高騰が地 主を追い出しているのではなく，都心居住地は，地価高 騰による土地ポテンシャルの高まりを地主自身が享受で きる場所であることを明らかにしている。

都心居住地域におけるこれらの動向は，その土地柄の 良さを背景にしており，既存住民の定住意識が高ければ 今後もこの傾向は続くと考えられる。

また，「住民」とは誰かといった場合，マンションの オフィス利用の進行やマンション居住の仕方の多様化に より, 従来の定義ではとらえきれない状況になってきて いるといえよう。都心部の街のあり方を検討する上での 基礎指標（人口）を，住民登録だけで議論するのは不十 分であり，今後の発想の転換が望まれる。

最後に, 本研究は, 港区住宅地区における事例調查に 基づくものであり, 都心居住地域全域にこうした現象が 生じているかどうかについては，その土地柄や，家貨相 場・地価等の経済的条件により多少の差があると考えら れる。今後はこうした調查・研究を新宿, 文京, 台東と いった地域に展開していくことが必要であろう。

本研究をまとめるに当たりご指導いただいた東京大学 工学部教授伊藤 滋先生, 早稲田大学大学院講師鈴木信 太郎先生に深く感謝します。

\section{参考文献および注}

1）住宅政策の新たな展開のために一早急に取り組むべき対 策一, 東京都住宅政策懇談会, 昭和 63 年 10 月

2）千代田区基本構想，昭和 53 年 6 月

3）中央区基本構想，昭和 56 年 6 月

4）大江守之：都心地域における人口減少構造一千代田区を 事例として一, 都市計画学術論文集第 18 号, p. 259 264, 昭和 58 年

5）岡田知子 富樫 顶：都心業務地区における定住要因に 関する研究一大阪市船場地区の場合一, 都市計画学術論 文集第 20 号, p. 163 168, 昭和 60 年

6) 中島高志：台東区住商併用地域における人口安定地区に ついての考察, 都市計画学術論文集第 20 号, p. 169 174, 昭和 60 年

7）中央区第 2 次基本計画，昭和 61 年 2 月

8）港区街ブくりマスタープラン，昭和 63 年

9）中林一樹 大江守之：永年居住者の居住動向之建物更新 からみた東京都心地域における都市更新之定住化に関す る研究, 都市計画学術論文集第 19 号, p. 499 504, 昭和 59 年

10）田端 修 鳴海邦碩 土肥絵理子：都心居住者の環境評 価に関する考察一大阪都市地域旧来型市街地居住者調查 を通じて一, 都市計画学術論文集第 20 号, p. 175 180, 昭和 60 年

11）大江守之：東京都心地域における土地利用及び土地所有 
の変化と居住者の動向, 都市計画学術論文集第 21 号, p. $277 \sim 282$, 昭和 61 年

12）（財）森記念財団：港区の環境カルテその 2 , 昭和 60 年 10 月

13）昭和 60 年より住民票個票の閲覧が不可能となった。本研 究では, (財) 森記念財団が昭和 59 年に収集した住民票 データの分析結果を引用した。

14）従前については住宅地図。例えば,工場併用住宅であれば, 工場 1 , 住宅 1 。従後のマンションについては, オフィス 利用が確認できた住戸は非住居, それ以外は住居として 確認した。

15）住宅地図による調查のため，戸数については若干の誤差 があろう。

16）住民登録率については（表一7）のとおり。

17）国調によると，港区の単身世帯数は 17495 世帯（昭和 50 年）から，27336 世帯（昭和 60 年）に増加し，全世帯に 占める割合も $25.6 \%$ から $35.9 \%$ に高まった。

18）ただし，謄本等により，給与住宅であることが確認でき たものは除いた。

19）借地権の売却を含む。借地権については，新築建物所有 者が，従前に居住していた者と異なる場合は売却された ものとみなした。なお，所有権が移転しないケースで， 従前従後の居住者が異なる例はなかった。

20）中林一樹-大江守之：永年居住者の居住動向と建物更新 からみた東京都心地域における都市更新と定住化に関す る研究, 都市計画学術論文集第 19 号, p. 499 504, 昭和 59 年; におけるアンケート調査からも同様の傾向が報告 されている。

21）現地調査によれば，従前 22 戸の工場が建て替わっている が，そのうちの 15 戸 $(68.2 \%)$ は從後も工場としての機
能を残している。

22）都市型工業の都心立地のメリットについては以下の報告 書等で明らかにされている。

港区工業実態調查報告書, 昭和 62 年 3 月

港区における工業振興策のあり方について 答申，昭和 63 年 9 月

地域産業活性化のための政策プログラム一墨田区工業振 興マスタープランー, 昭和 63 年 3 月

東京商工会議所：21 世紀産業社会における都市型工業の あり方，昭和 63 年 9 月

23）（財）森記念財団：港区の環境カルテその 3, 昭和 61 年 12 月

24）大江守之：東京都心地域における土地利用及び土地所有 の変化と居住者の動向, 都市計画学術論文集第 21 号, p. $277 \sim 282$, 昭和 61 年

25）マンションの住民登録について調査した報告書には以下 のものがある。

国土庁大都市圏整備局：東京都心における人口定着化の 実態に関する調査，昭和 56 年 3 月

(財) 日本住宅総合センター：都心周辺区における職業分 布と職住混合の形態に関する調查, 昭和 62 年 10 月

26）大江守之・中林一樹：東京都心地域における新規定着層 の居住動向と定住意識, 都市計画学術論文集第 19 号, p. $505 \sim 510$, 昭和 59 年;においても，相当割合が複数の 住宅を持ち，ネットワーク居住とでも呼ぶべき住まい方 がされていることが明らかになっている。

27）ただし, 複合地区における事例であるため, 居住者の特 性（家族タイプ・居住歴等）については住宅地区におけ るマンションの居住者とは若干異なる可能性がある。 


\section{SYNOPSIS}

UDC : $711.12: 711.1$

FACT FINDING STUDY OF TRANSFIGURATION OF INNER RESIDENTIAL DISTRICT

Case study of Minato Ward, Tokyo (1980-87)

by Dr. SHINGo YAMASHITA, Chief Researcher, Mori Memorial Foundation, and YASUYUKI MIWA, Researcher, Mori Memorial foundation, Members of A. I. J.

This study tries to find out the main characteristics of transfiguration of inner city residential district, and inhabitants of apartment buildings by field work at residential district of Minato Ward, Tokyo.

The summary of findings are as follows:

1. The expansion of office space as is observed in the business district is only the phenomenon along main streets, restructuring of houses into houses are common at the inner part of residential district, and therefore housing units have been increased considerably.

2. The restructuring of houses have been carried out mainly by native residents who are proprietors, and they try to stay on their land keeping their rights as owners of new buildings enjoying the realestate proceeds. Uprising land price is not forcing the owners to forgive their properties in the district.

3. The number of apartment houses, so called "Mansion" is increasing by restructuring. New "Mansion" residents usually stay there for a short period of time such as one or two years, and approximately half of them apply resident registration. The non-residence use is prevailing in the "Mansion", and there are many varieties even within the residence use. Non-registered residents have become considerable portion in the district which could not be disregarded. Population by resident registration is not more sufficient as a basic criterion for the administrative judgement. 